\title{
Bile Changes after Liver Surgery: Experimental and Clinical Lessons for Future Applications
}

\author{
Gianpiero Gravante $^{\mathrm{a}}$ Timothy Knowles $^{\mathrm{b}}$ Seok Ling Ong ${ }^{\mathrm{a}} \quad$ Omer Al-Taan $^{\mathrm{a}}$ \\ Matthew Metcalfe $^{a} \quad$ Ashley R. Dennison $^{a} \quad$ David M. Lloyd ${ }^{a}$

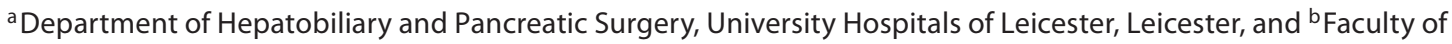 \\ Medicine and Dentistry, University of Bristol, Bristol, UK
}

\section{Key Words}

Bile analysis • Bile composition - Bile secretion • Biliary

acids $\cdot$ Liver failure $\cdot$ Liver resection $\cdot$ Liver transplant

\begin{abstract}
Introduction: The aim of this review is to summarize the available evidence for changes in bile composition following liver surgery and assess their use in predicting post-operative complications. Materials and Methods: A literature search was undertaken for all studies focusing on bile composition, bile volume and analysis. Articles were selected from MEDLINE, Embase and the Cochrane Central Register of Controlled Trials databases up to May 2009. Results: Low values of pre-operative bilirubin diglucuronide predict reduced post-operative liver function and the occurrence of jaundice. Low concentrations of hepatocyte growth factor and interleukin- 6 in bile following surgery are associated with the subsequent development of liver failure and are probably surrogate markers for situations where the resultant hepatic regeneration is inadequate. Conclusions: Analysis of the composition and quality of bile is probably underused as a tool for the pre-operative screening and early post-operative monitoring of patients at high risk of developing liver failure following major hepatobiliary procedures.
\end{abstract}

Copyright $\odot 2010$ S. Karger AG, Basel

\section{Introduction}

During periods of fasting, bile, which is secreted by the liver, is concentrated and stored in the gallbladder. The composition of bile is complex, but bile acids are the most abundant constituents of human bile. Over $95 \%$ of the bile acids entering the duodenum are conserved and returned to the liver after reabsorption in the terminal ileum (enterohepatic circulation). Their rate of absorption exerts a regulatory effect upon both bile flow and the concentrations of other biliary lipids (phospholipids and cholesterol). Bile acid-dependent flow is related to bile acid secretion and accounts for the greatest proportion (70-85\%) of canalicular flow [1]. Bile acid-independent bile flow is thought to be driven by inorganic ion transport [2] and is both canalicular and ductal [1].

Disruption of the normal physiological production of bile leads to pathological conditions of varying severity. Some degree of liver failure is inevitable following major liver surgery and particularly formal resections, ablation of liver tissue and tumours and major biliary reconstructions, but unless resolution is rapid and uncomplicated, potentially serious complications are possible. This type of post-operative liver failure is characterized by a markedly elevated serum bilirubin, hepatic encephalopathy and the myriad sequelae of an impaired ability to synthe-

\section{KARGER}

Fax +4161306 1234 E-Mail karger@karger.ch www.karger.com
Dr. Gianpiero Gravante

Department of Hepatobiliary and Pancreatic Surgery

Leicester General Hospital

Gwendolen Road, Leicester LE5 4PW (UK)

E-Mail ggravante@ hotmail.com 
size proteins [3]. Its incidence following hepatobiliary (HPB) surgery is estimated at $10-20 \%$ [4-6], and it is associated with a high mortality rate. A simple and reliable laboratory test would be invaluable and allow clinicians to identify patients whose post-operative outcome is likely to be complicated. Serum biochemical tests are available but have been shown to have a relatively low specificity in comparison to the direct analysis of bile [7]. Using both experimental models and clinical studies, different groups have identified a number of changes that occur in bile secretion and composition, and have also shown them to be early predictors of liver function following surgery. The purpose of this review is to summarize the available evidence in respect of these changes and determine whether they could be used as a potential screen in the clinical setting to indicate patients at high risk of developing significant post-operative complications.

\section{Materials and Methods}

A literature search was undertaken for all studies focusing on modifications of bile volume or composition as a consequence of liver surgery. Articles were selected from MEDLINE, Embase and the Cochrane Central Register of Controlled Trials databases up to May 2009.

The search strategy was conducted using three different sets of key words, one for HPB surgery, one for bile characteristics and one for outcome measures. Key words used for HPB surgery were: HPB resection, liver resection, hepatectomy, partially hepatectomized rats, biliary tract surgical procedures, obstructive jaundice, transplantation, orthotopic transplantation, and liver transplantation. Key words used for bile characteristics were bile, bile composition, bile flow, bile acids and salts, biliary lipids, cholesterol saturation, bile bilirubin, bilirubin subfractions, hyperbilirubinaemia, hormones, hepatocyte growth factor (HGF), inflammatory cytokines, and interleukin-6 (IL-6). Key words used for outcome measures were liver regeneration, post-operative liver failure, prognosis, and allograft rejection. All types of studies were included in the search strategy. No language restrictions were employed.

Potentially relevant articles were identified by the title and the abstract, and full papers were obtained and assessed in detail by two of the authors (T.K. and G.G.) prior to their inclusion in the review. The reference list for each article (including copies of previously published reviews on the topic) was also screened to identify further relevant publications which were obtained and assessed. Finally, the Current Controlled Trials (www.controlledtrials.com) database was also screened for randomised trials currently ongoing.

Data collection and analysis was carried out independently by 2 researchers (T.K. and G.G.). Studies were classified into two groups which investigated either pre-clinical or clinical investigations and/or outcomes.

Bile Changes after Liver Surgery

\section{Results}

After the initial search, ninety-nine potentially relevant articles were retrieved and assessed in detail and eighteen of them were discarded. One was the original description of the surgical technique of orthotopic liver transplantation (OLTx) [8], one focused on biliary tract histology [9] and nine only on serum factors [10-16] or other factors but not including bile samples $[17,18]$. One study examined the effects of taurocholic acid administration [19], one HGH uptake in the liver [20], one postoperative biliary obstructions only [21], one liver regeneration only [22], one the influence of bile salts on cyclosporine absorption [23] and two were letters to the editor $[24,25]$. Eighty-one articles were suitable for the analysis including twenty experimental studies and sixty-one clinical studies (tables 1-3).

\section{Liver Transplantation}

Changes in hepatic secretory function in relation to all aspects of bile flow and composition have been investigated extensively (table 1). Clearly distinct stages following liver transplantion have been identified, and during these stages various factors influence the physiology and production of bile. Immediately after transplantation, the most influential factor is the recovery from cold ischaemia (1-3 h), and acute rejection or immunosuppressive drugs exert their influence later (7-14 days and 3-4 weeks, respectively). The first study to analyse bile composition in an animal model of OLTx found that during rejection episodes bile volume and bile acid output were significantly decreased [26]. Modifications of bile composition and volume were attributed to the restitution of the liver blood flow, while the duration of the cold ischaemia was a significant exacerbating factor [27], and these results suggested that post-operative bile changes were representative of the early graft function [27]. Later changes in bile volume and bile salt synthesis and secretion at 2 weeks and one month following an uneventful OLTx show changes which are significantly different from those seen immediately after recovery (table 1). Such modifications in bile composition are probably due to the influence of immunosuppressive drugs [28, 29]. Both experimental [26, 29-31] and clinical studies [32-34] have confirmed that various immunosuppressive drugs exert different effects on bile flow and composition (table 1).

Different factors have been investigated in clinical studies of OLTx as potential predictors of post-operative complications and graft function. Sub-optimal donor livers demonstrate a low choleretic activity and an altered

Dig Surg 2010;27:450-460 
Table 1. Studies on orthotopic liver transplantation and liver ischaemia

\begin{tabular}{|c|c|c|c|c|}
\hline $\begin{array}{l}\text { Topic } \\
\text { investigated }\end{array}$ & Author & Subjects & Model & Results \\
\hline OLTx & $\begin{array}{l}\text { McMaster [26], Chan et al. [28], Chan et al. } \\
\text { [29], Tono et al. [78], Daloze et al. [79], } \\
\text { Chan et al. [80] }\end{array}$ & $\begin{array}{l}\text { Rhesus } \\
\text { monkeys, } \\
\text { rats, } \\
\text { dogs }\end{array}$ & OLTx & $\begin{array}{l}\uparrow \text { or normal bile volume } \\
\text { Normal bile salt output, secretion, synthesis and pool } \\
\text { size, phospholipids secretion } \\
\downarrow \text { or normal cholesterol secretion } \\
\text { No differences if the allograft only receives blood from } \\
\text { the portal vein } \\
\text { Immunology: } \uparrow \text { bile IL-6, decreasing after } 48 \mathrm{~h} \text { and } \\
\text { maintaining low levels afterwards }\end{array}$ \\
\hline
\end{tabular}

\begin{tabular}{llll}
\hline Immuno- & McMaster [26], Chan et al. [29], Le Thai et & Rhesus & OLTx + different \\
suppression & $\begin{array}{l}\text { al. [30], Chan et al. [31], Bell et al. [81], Le } \\
\text { Thai et al. [82], Stone et al. [83], Stone et al. }\end{array}$ & $\begin{array}{l}\text { monkeys, } \\
\text { [84] }\end{array}$ & rats
\end{tabular}

Azathioprine and prednisolone: normal or $\downarrow$ bile volume [84]

monkeys, immunosuppressive Normal bile salt output, concentration, synthesis,

secretion and pool size, phospholipids secretion,

cholesterol secretion and concentration

Cyclosporine: $\downarrow$ bile flow and volume, bile salt output, concentration, synthesis, secretion and pool size $\downarrow$ phospholipids secretion. Normal cholesterol secretion and concentration

\begin{tabular}{lll}
\hline Rejection McMaster [26], Tono et al. [78] & $\begin{array}{l}\text { Rhesus OLTx with rejection } \\
\text { monkeys, } \\
\text { rats }\end{array}$
\end{tabular}

$\downarrow$ bile volume, bile salt output and concentration Normal cholesterol concentration Immunology: $\uparrow$ bile IL-6, correlated with the histological severity of rejection

Ischaemia Kamiike et al. [43], Xu et al. [27], Bowers et Rats

In vivo: induced Ischaemia $>\downarrow$ ATP $>\downarrow$ or stop of bile volume and flow, $\downarrow$

time al. [85] ischaemia (clamping) bile salt concentration, secretion, synthesis and pool size, L-Ethionine $(=\downarrow$ ATP) phospholipids concentration and secretion. Normal or $\uparrow$ Ex vivo: reperfusion cholesterol concentration and secretion with bicarbonate/ More prolonged ischaemia $=$ further $\downarrow$ bile volume and albumin solution flow, recovery more depressed

OLTx Javitt et al. [86], Ericzon et al. [38], Baiocch et al. [39], Tisone et al. [40], Sanchez-Bueno et al. [42], Umeshita et al. [48], Carrasco et al. [51], Baiocchi et al. [87], Baumgartner et al. [41], Goresky et al. [88], Melendez et al. [35], Kubota et al. [52], Geuken et al. [36], Haagsma et al. [89], McCashland et al. [32], Ko et al. [33], Shiffman et al. [90], Waldram et al. [91], Lenzen et al. [92], Bowers et al. [93], Umeshita et al. [94], Ericzon et al. [95], Roberti et al. [53], Theilmann et al. [96], Carrasco et al. [97], Oldhafer et al. [98], Kubota et al. [99], Kubota et al. [100], McMaster et al. [101], McMaster et al. [102]

Patients OLTx

Steady increase in bile flow, in bile salt output, synthesis, secretion, concentration and pool size, of cholesterol and phospholipids secretion and concentration after OLTx Bilirubin subfractions $\downarrow$ BDG, $\uparrow$ BMG

Electrolyte, glucose, urea and creatinine concentrations similar to plasma

T-tube open (first p.o. days) = bile supersaturated with cholesterol = 'early' biliary sludge

T-tube clamped $=$ re-establishment of enterohepatic circulation $=\uparrow$ bile salt $=$ bile unsaturated with cholesterol Immunology: $\uparrow$ bile IL-6, decreasing after $48 \mathrm{~h}$ and maintaining low levels afterwards Cytology: cells for the first 5 days, with the highest cell density on p.o. day 1 (PMN, ductal and ghost cells), then decrease afterwards

Polarizing and electron microscopy: increased proportion of vesicles and reduction of their size, presence of lamellae

Immuno- McCashland et al. [32], Ko et al. [33],

suppression Ericzon et al. [34], Söderdahl et al. [103], Sauer et al. [104]
Patients OLTx + CyA

OLTx + FK 506

OLTx + Cya versus

FK 506
CyA: steadily increase in bile flow, bile salt output and secretion

Normal bile salt concentration, $\downarrow$ deoxycholic and chenodeoxycholic acid synthesis, $\uparrow$ relative concentration cholic acid. Bile salt, cholesterol and phospholipid concentration correlated with serum CyA levels FK506: steadily increase of bile flow, bile salt output and secretion, cholesterol and phospholipid secretion, more marked than with CyA

Normal bile salt concentration, $\downarrow$ deoxycholic acid synthesis 
Table 1 (continued)

\begin{tabular}{|c|c|c|c|c|}
\hline $\begin{array}{l}\text { Topic } \\
\text { investigated }\end{array}$ & Author & Subjects & Model & Results \\
\hline PNF & $\begin{array}{l}\text { Ericzon et al. [38], Tisone et al. [40], } \\
\text { Sanchez-Bueno et al. [42], Carrasco et al. } \\
\text { [51], Baumgartner et al. [41], Melendez et } \\
\text { al. [35], Umeshita et al. [94], Carrasco et al. } \\
\text { [97] }\end{array}$ & Patients & OLTx with PNF & $\begin{array}{l}\downarrow \text { bile volume and flow, bile salt output and secretion, } \\
\text { extremely low or undetectable concentrations of bile salt, } \\
\text { cholesterol and phospholipids until recovery } \\
\text { Immunology: normal IL-6 } \\
\text { Cytology: high cell density since OLTx until retransplant } \\
\text { (PMN, ductal cells) }\end{array}$ \\
\hline Rejection & $\begin{array}{l}\text { Ericzon et al. [38], Sanchez-Bueno et al. } \\
\text { [42], Umeshita et al. [48], Carrasco et al. } \\
\text { [51], Baumgartner et al. [41], Goresky et al. } \\
\text { [88], Kubota et al. [52], Haagsma et al. [89], } \\
\text { Adams et al. [49], Adams et al. [45], } \\
\text { Hathaway et al. [46], Hathaway et al. [105], } \\
\text { Ko et al. [33], Akamatsu et al. [106], Lenzen } \\
\text { et al. [92], Adams et al. [50], Umeshita et al. } \\
\text { [94], Roberti et al. [53], Adams et al. [107], } \\
\text { Carrasco et al. [97], Hathaway et al. [108], } \\
\text { Oldhafer et al. [98], Kubota et al. [99], } \\
\text { Kubota et al. [100] }\end{array}$ & Patients & OLTx with rejection & $\begin{array}{l}\downarrow \text { bile volume, bile salt, cholesterol and phospholipids } \\
\text { concentration } \\
\text { No differences according to histological severity of } \\
\text { rejection } \\
\text { Bilirubin subfractions: } \downarrow \text { BDG, } \uparrow \text { BMG } \\
\text { Immunology: } \uparrow \text { in bile chemotactic activity for CD3+ and } \\
\text { CD8+ lymphocytes, monocytes and neutrophils. } \uparrow \text { bile } \\
\beta_{2} \text {-microglobulin, } \uparrow \text { IL-2 receptor, } \uparrow \text { IL- } 6 \text {. } \uparrow \text { IgG and IgM } \\
\text { No differences according to histological severity of } \\
\text { rejection } \\
\text { Cytology: high cell density (PMN, MN, macrophages, } \\
\text { lymphocytes, blasts, ghost cells). Contrasting results for } \\
\text { correlation of cell density and blasts with histological } \\
\text { grades }\end{array}$ \\
\hline IPF & Tisone et al. [40] & Patients & OLTx with IPF & $\begin{array}{l}\text { Delayed bile salt output, synthesis, concentration and } \\
\text { secretion }\end{array}$ \\
\hline $\begin{array}{l}\text { Vascular } \\
\text { thrombosis }\end{array}$ & $\begin{array}{l}\text { Ericzon et al. [38], Akamatsu et al. [106], } \\
\text { Bowers et al. [93], Roberti et al. [53], } \\
\text { Oldhafer et al. [98], Kubota et al. [100] }\end{array}$ & Patients & $\begin{array}{l}\text { OLTX with HA or } \\
\text { vena cava thrombosis }\end{array}$ & $\begin{array}{l}\text { Sharp decline of bile salt output, synthesis, concentration } \\
\text { and secretion until extremely low concentration } \\
\text { Bilirubin subfractions: } \downarrow \text { BDG, } \uparrow \text { BMG } \\
\text { Cytology: high cell density (PMN, MN, lymphocytes, } \\
\text { ductal cells) }\end{array}$ \\
\hline Sepsis & $\begin{array}{l}\text { Carrasco et al. [51], Akamatsu et al. [106], } \\
\text { Adams et al. [50], Umeshita et al. [94], } \\
\text { Roberti et al. [53], Carrasco et al. [97], } \\
\text { Kubota et al. [99], Kubota et al. [100], } \\
\text { McMaster et al. [102] }\end{array}$ & Patients & $\begin{array}{l}\text { OLTx with HPB } \\
\text { sepsis } \\
\text { (e.g. cholangitis) }\end{array}$ & $\begin{array}{l}\text { Bilirubin subfractions: } \downarrow \text { BDG, } \uparrow \text { BMG } \\
\text { Obstruction }>\text { cholangitis }>\text { unconjugation of bilirubin }> \\
\text { 'late’ biliary sludge } \\
\text { Immunology: } \uparrow \text { IL- } 2 \text { receptor, } \uparrow \text { IL- } 6 \\
\text { Cytology: high cell density during the episode (PMN) }\end{array}$ \\
\hline $\begin{array}{l}\text { Biliary } \\
\text { strictures }\end{array}$ & Geuken et al. [36], Buis et al. [37] & Patients & $\begin{array}{l}\text { OLTx with p.o. } \\
\text { biliary strictures }\end{array}$ & $\begin{array}{l}\downarrow \text { bile salt, cholesterol and phospholipids secretion } \\
\uparrow \text { bile acid/phospholipid ratio (increased cytotoxicity for } \\
\text { bile duct cells) }\end{array}$ \\
\hline $\begin{array}{l}\text { Sub-optimal } \\
\text { donors }\end{array}$ & Melendez et al. [35] & Patients & $\begin{array}{l}\text { OLTx from sub- } \\
\text { optimal donors }\end{array}$ & $\downarrow$ bile flow \\
\hline $\begin{array}{l}\text { Ischaemia } \\
\text { time }\end{array}$ & Carrasco et al. [109] & Patients & $\begin{array}{l}\text { Correlation with } \\
\text { ischaemia time }\end{array}$ & $\begin{array}{l}\text { Inverse relationship with ATP recovery }>\downarrow \text { graft function } \\
>\downarrow \text { bile production } \\
\text { Cytology: increased cell density and ductal cells with } \\
\text { longer ischaemia time }\end{array}$ \\
\hline
\end{tabular}

HA = Hepatic artery; p.o. = post-operative; PMN = neutrophil polymorphonuclear leucocytes; $\mathrm{MN}=$ mononuclear leukocytes; CyA = cyclosporine.

bile acid composition when compared to normal grafts [35]. Bile cytotoxicity (measured by an increase in the bile salt/phospholipid ratio) appears to be involved in the pathogenesis of non-anastomotic biliary strictures [36, 37]. In transplant recipients, a progressive increase in the bile salt pool and concentration is seen in functioning grafts as opposed to those with initial poor function (IPF) or primary non-function (PNF) [38-41]. In grafts with IPF, there is an initial, transient incapacity to synthetize and secrete bile salts, while in PNF this is permanently impaired $[38,40]$. These differences mean that sequential monitoring of biliary bile salt secretion is able to reliably discriminate between the two conditions [40]. A reduction in bile flow and bile lipids is also found with both 
PNF and acute rejection, but was more marked in the former [41, 42]. Hepatic energy status (and hence organ viability) influences the recovery of normal liver function after ischaemia and liver transplantation. Higher levels of hepatic ATP result in a higher rate of bile secretion after controlled ischaemia [43] and a reduced rate of post-operative rejection in the transplant recipients [44].

Potentially, the most interesting findings relate to the early diagnosis of rejection. Bile samples taken 2-3 days before clinical symptoms become apparent are chemotactic for lymphocytes, monocytes and neutrophils to an even greater extent than those collected during the episode itself $[45,46]$. IL- 6 , an important component of the signalling pathway for hepatocyte proliferation and liver regeneration [47] may explain this chemotactic activity and has been shown to be elevated in the bile of patients experiencing rejection episodes [48]. Similar results are found for $\beta_{2}$-microglobulin, a molecule associated with particular HLA class 1 antigens [49], and for IL-2 receptor [50]. It is likely that CD8+ T lymphocytes are recruited in response to IL-6 (and other chemotactic factors) secreted by CD4+ cells significantly before the onset of the symptoms of rejection [46]. Following this recruitment, the bile cellularity starts to increase, usually $24 \mathrm{~h}$ before the clinical symptoms [51-53]. In this setting, the analysis of bile may provide a useful screening tool for patients who are experiencing leukocyte activation and recruitment but are still in the asymptomatic phase of the rejection.

\section{Liver Resection}

The analysis of bile flow and composition has also been used to assess changes in hepatic secretory function following HPB surgery (table 2). In experimental studies, liver resection had a greater effect on the rate of secretion of bile salts, cholesterol and phospholipids than their final concentration in the bile $[54,55]$. Liver regeneration affected the total volume of bile and its rate of secretion following liver resection. The maximum reduction occurs between 12 and $48 \mathrm{~h}$ post-operatively, and from days 3 and 9 recovers to normal levels as liver regeneration proceeds $[55,56]$.

There are also a number of clinical studies which have investigated the ability of modifications in bile composition to predict the incidence of liver failure after surgical resection. Pre-operative and post-operative bile salt concentrations on day 2 have the highest predictive power for post-operative liver failure, suggesting that these measurements could indicate patients at high risk of developing complications [7], and these results also confirmed those obtained in experimental studies [56]. Furthermore, they are also supported by subsequent clinical studies that demonstrated a normalization of bile composition after the second post-operative day which coincides with liver regeneration [57].

The proportions of the biliary bilirubin subfractions are usually altered in HPB diseases [58]. Pre-operative changes in jaundiced patients consist of lower levels of pre-operative bilirubin diglucuronide (BDG) and higher levels of bilirubin monoglucuronide (BMG), corresponding to a lower BDG:BMG ratio and less efficient bile processing. Such modifications have been shown to be predictive of post-operative liver function after hepatic resections [3], and furthermore liver resection per se exerts an additional influence on the normal production of biliary bilirubin subfractions, further decreasing BDG and increasing BMG from the 5th to the 21st post-operative day $[59,60]$. A significant correlation was also found with the energy state of the remnant liver [60], confirming the importance of the hepatic ATP on the post-operative outcomes [43].

Finally, after hepatic parenchymal loss, regeneration is stimulated by a number of different factors, including HGF - a potent hepatocyte mitogen. Biliary HGF correlates with the remnant liver volume after hepatectomy and shows an increased specificity for the detection of post-operative liver failure as opposed to serum HGF [61, 62]. Similar results are also obtained for IL-6 [63].

\section{Biliary Drainage}

Pre-operative biliary drainage and the particular method used have also been shown to influence the amount of liver regeneration occurring after surgery (table 3). Internal biliary drainage is superior to external biliary drainage stimulating more liver regeneration demonstrated by an increased rate of hepatic DNA synthesis, liver function, liver weight, bile flow, bile salt and phospholipid secretion in the internally drained group [64-66]. External biliary drainage markedly suppresses regenerative capacity [67], while with internal biliary drainage it is preserved [64]. This suggested that the bile itself contains important factors that are involved in hepatocyte regeneration, and that these factors are irreversibly removed by external drainage with adverse effects on liver regeneration. HGF is physiologically reabsorbed from the gastrointestinal tract into the portal venous circulation and is likely to be one of these factors $[68,69]$. The continuous loss of bile resulting from external drainage may reduce this reabsorption, stimulating additional HGF secretion in the bile [69]. As a con- 
Table 2. Studies on the effects of liver resection and regeneration

\begin{tabular}{|c|c|c|c|c|}
\hline Author & Year & Subject & Model & Results \\
\hline $\begin{array}{l}\text { Fukano } \\
\text { et al. [54] }\end{array}$ & 1985 & Rats & (1) $66 \% \mathrm{HT}$ & $\begin{array}{l}\uparrow \text { bile flow and bile salt, cholesterol, phospholipid secretion until p.o. } \\
\text { day } 4 \\
\uparrow \text { cholic acid, } \downarrow \text { chenodeoxycholic acid until p.o. day } 7 \\
\downarrow \text { pool size until p.o. day } 14\end{array}$ \\
\hline $\begin{array}{l}\text { Perez- } \\
\text { Barriocanal } \\
\text { et al. [55] }\end{array}$ & 1987 & Rats & $\begin{array}{l}\text { (1) } 66 \% \mathrm{HT} \\
\text { (2) controls }\end{array}$ & $\begin{array}{l}\text { Concentration: normal for bile salt and phospholipid from } 12 \mathrm{~h} \text { to } 16 \\
\text { days p.o., } \downarrow \text { for cholesterol } \\
\text { Secretion: } \downarrow \text { for bile salt, cholesterol and phospholipid at } 12 \text { to } 24 \mathrm{~h} \text { p.o., } \\
\text { normal thereafter }\end{array}$ \\
\hline $\begin{array}{l}\mathrm{Xu} \\
\text { et al. [56] }\end{array}$ & 1993 & Rats & $\begin{array}{l}\text { (1) } 75 \% \text { HT }(\mathrm{n}=8) \\
\text { (2) } 50 \% \text { HT }(\mathrm{n}=8) \\
\text { (3) controls }(\mathrm{n}=8)\end{array}$ & $\begin{array}{l}\text { Liver size approached controls on (1) day } 9 \text { or (2) day } 7 \text { p.o. } \\
\downarrow \text { Bile flow and volume on day } 1 \text { and } 3 \text { for (1) and (2), normal on day } 5 \\
\text { p.o. } \\
\downarrow \text { bile salt secretion, synthesis and pool size, cholesterol and } \\
\text { phospholipid secretion on day } 1-5 \text { p.o. for (1) and (2) }\end{array}$ \\
\hline $\begin{array}{l}\text { Igarashi } \\
\text { et al. [59] }\end{array}$ & 1999 & Rats & $\begin{array}{l}\text { (1) } 80 \% \mathrm{HT} \\
\text { (2) } 70 \% \mathrm{HT} \\
\text { (3) controls }\end{array}$ & $\begin{array}{l}\downarrow \text { BDG and UDP-GA from day } 5 \text { to } 21 \text { p.o. for (1) and (2) vs. (3) } \\
\downarrow \text { UDP-GT activity at } 12 \text { hours for (1) and (2) vs. (3) } \\
\uparrow \text { BMG and other subfractions from day } 3 \text { to } 21 \text { p.o. for (1) and (2) vs. } \\
\text { (3) }\end{array}$ \\
\hline $\begin{array}{l}\text { Suto } \\
\text { et al. [60] }\end{array}$ & 2002 & Rats & $\begin{array}{l}\text { (1) } 33 \% \text { HT with sepsis } \\
\text { (2) } 33 \% \text { HT } \\
\text { (3) sepsis } \\
\text { (4) controls }\end{array}$ & $\begin{array}{l}\downarrow \text { BDG, UDP-GA, UDP-GT and NAD+ on p.o. day } 3 \text { and } 4 \text { for }(1) \text { and } \\
\text { (3) vs. ( } 2 \text { ) and ( } 4 \text { ) } \\
\uparrow \text { BMG on day } 3 \text { and } 4 \text { for ( } 1 \text { ) and (3) vs. ( } 2) \text { and ( } 4) \\
\text { Normal UDP-glucose, UDP-GDH activity, and cytosolic free (NAD+)/ } \\
\text { (NADH) ratio }\end{array}$ \\
\hline $\begin{array}{l}\text { Takeuchi } \\
\text { et al. [61] }\end{array}$ & 1997 & Patients & $\begin{array}{l}\text { (1) } 1 \mathrm{EBD}>\mathrm{HT} \text { or extended HT without liver } \\
\text { failure }(\mathrm{n}=20) \\
\text { (2) } \mathrm{EBD}>\mathrm{HT} \text { or extended HT with liver failure } \\
(\mathrm{n}=4)\end{array}$ & $\begin{array}{l}\text { 1. } \uparrow \text { bile HGF from p.o. day } 1 \text { to } 7 \\
\text { 2. Normal bile HGF after surgery (no increase) }\end{array}$ \\
\hline $\begin{array}{l}\text { Ishiyama } \\
\text { et al. [3] }\end{array}$ & 1998 & Patients & $\begin{array}{l}\text { (1) } \mathrm{EBD}>\mathrm{HT} \text { without liver failure }(\mathrm{n}=10) \\
\text { (2) } \mathrm{EBD}>\mathrm{HT} \text { with liver failure }(\mathrm{n}=5) \\
\text { (3) } \mathrm{EBD}>\text { controls }(\mathrm{PD} ; \mathrm{n}=8)\end{array}$ & $\begin{array}{l}\downarrow \text { BDG and } \uparrow \text { BMG on p.o. day } 1 \text { for (1), (2) and (3). On p.o. day } 14 \\
\text { normal for (3) and (1), } \downarrow \text { for (2) }\end{array}$ \\
\hline $\begin{array}{l}\text { Kurumiya } \\
\text { et al. [62] }\end{array}$ & 1999 & & $\begin{array}{l}\text { (1) HT + bile duct resection }(\mathrm{n}=21) \\
\text { (2) HT }+\mathrm{PD}(\mathrm{n}=10) \\
\text { (3) } \mathrm{PD}(\mathrm{n}=15) \\
\text { (4) bile duct resection }(\mathrm{n}=4)\end{array}$ & $\begin{array}{l}\uparrow \text { bile HGF from p.o. day } 1 \text { to } 7 \\
\uparrow \text { bile HGF after bile duct resection as well as after HT }\end{array}$ \\
\hline $\begin{array}{l}\text { Maeda } \\
\text { et al. [63] }\end{array}$ & 1999 & Patients & $\begin{array}{l}\text { (1) } \text { EBD }>\text { HT or extended HT without liver } \\
\text { (2) failure }(\mathrm{n}=18) \\
\text { EBD }>\text { HT or extended HT with liver failure } \\
(\mathrm{n}=6)\end{array}$ & $\uparrow$ bile IL- 6 from p.o. day 1 to 6 for (1) and (2), but lower values for (2) \\
\hline $\begin{array}{l}\text { Kurumiya } \\
\text { et al. [7] }\end{array}$ & 2003 & Patients & $\begin{array}{l}\text { (1) } \mathrm{EBD}>\text { HT without liver failure }(\mathrm{n}=29) \\
\text { (2) } \mathrm{EBD}>\mathrm{HT} \text { with liver failure }(\mathrm{n}=7) \\
\text { (3) } \mathrm{EBD}>\text { controls (PD or bile duct resection; } \\
\mathrm{n}=15)\end{array}$ & $\begin{array}{l}\downarrow \text { bile flow, bile salt secretion and concentration, cholesterol and } \\
\text { phospholipid concentration on p.o. day } 1 \text { and thereafter increased in } \\
\text { (1) and (3) but not in }(2) \\
\text { Correlation of bile salt concentration and secretion with remnant liver } \\
\text { clearance of indocyanine } \\
\text { Bile salt concentration predicts p.o. liver failure: } 81 \% \text { accuracy when } \\
\text { dosed preoperatively, } 88 \% \text { post-operatively }\end{array}$ \\
\hline $\begin{array}{l}\text { Hotta } \\
\text { et al. [57] }\end{array}$ & 2005 & Patients & $\mathrm{HT}+\mathrm{EBD}$ & $\begin{array}{l}\downarrow \text { bile salt concentration on p.o. day } 2 \text {, normal on day } 7 \\
\text { Cirrhosis and patients with poor remnant liver clearance of } \\
\text { indocyanine maintained } \downarrow \text { bile salt concentration on day } 7\end{array}$ \\
\hline
\end{tabular}

HT = Hepatectomy; PD = pancreatoduodenectomy; UDP-GA = uridine diphosphoglucuronic acid; UDP-GT = UDP-glucuronyltransferase; UDP$\mathrm{GDH}=\mathrm{UDP}$-glucose dehydrogenase; $\mathrm{NAD}+$ or $\mathrm{NADH}=$ nicotinamide adenine dinucleotide. 
Table 3. Studies on the effects of biliary drainage

\begin{tabular}{|c|c|c|c|c|}
\hline Author & Year & Subject & Model & Results \\
\hline $\begin{array}{l}\text { Iyomasa } \\
\text { et al. [67] }\end{array}$ & 1992 & Rats & $\begin{array}{l}70 \% \mathrm{HT} \text { and EBD } \\
70 \% \mathrm{HT} \text { and obstructive jaundice }\end{array}$ & $\begin{array}{l}\text { DNA polymerase- } \alpha \text { activities, mitotic index and ( } 3 \mathrm{H}) \text { thymidine } \\
\text { incorporation higher for (2) vs. (1) }\end{array}$ \\
\hline $\begin{array}{l}\text { Suzuki } \\
\text { et al. [64] }\end{array}$ & 1994 & Rats & $\begin{array}{l}70 \% \mathrm{HT} \text { and IBD } \\
70 \% \mathrm{HT} \text { and EBD } \\
70 \% \mathrm{HT} \text { and obstructive jaundice }\end{array}$ & $\begin{array}{l}\text { DNA polymerase- } \alpha \text { activities and mitotic index at p.o. day } 1 \text { and } \\
5 \text { days higher for (1) and (3) vs. (2) }\end{array}$ \\
\hline $\begin{array}{l}\text { Hayata } \\
\text { et al. [69] }\end{array}$ & 1999 & Rats & $\begin{array}{l}70 \% \text { HT and EBD }(\mathrm{n}=54) \\
30 \% \text { HT and external biliary drainage }(\mathrm{n}=54) \\
\text { EBD }(\mathrm{n}=54) \\
70 \% \text { HT }(\mathrm{n}=54) \\
30 \% \text { HT }(\mathrm{n}=54) \\
\text { Controls }(\mathrm{n}=54)\end{array}$ & $\begin{array}{l}\text { Liver weight was greater for (4) vs. (1) and (5) vs. (2) } \\
\text { HGF concentrations were lower for (4) vs. (1) and (5) vs. (2) }\end{array}$ \\
\hline $\begin{array}{l}\text { Saiki } \\
\text { et al. [65] }\end{array}$ & 1999 & Rats & $\begin{array}{l}70 \% \mathrm{HT} \text { and IBD } \\
70 \% \mathrm{HT} \text { and } \mathrm{EBD} \\
70 \% \mathrm{HT} \text { and obstructive jaundice }\end{array}$ & $\begin{array}{l}\text { Liver weight and hepatic DNA synthesis rate at p.o. day } 1 \text { and } 2 \\
\text { greater for (1) vs. (2) and for both vs. (3) }\end{array}$ \\
\hline $\begin{array}{l}\text { Mizuta } \\
\text { et al. [66] }\end{array}$ & 2002 & Rats & $\begin{array}{l}70 \% \mathrm{HT} \text { and IBD } \\
70 \% \mathrm{HT} \text { and } \mathrm{EBD} \\
70 \% \mathrm{HT} \text { and obstructive jaundice }\end{array}$ & $\begin{array}{l}\text { Liver weight, hepatic DNA synthesis, bile flow, bile salt secretion } \\
\text { and phospholipid secretion at p.o. day } 1 \text { and } 2 \text { greater for (1) vs. } \\
\text { (2) and for both vs. ( } 3 \text { ) } \\
\text { Similar cholesterol secretion among groups } \\
\text { Differences in biliary bile acid composition between (1) vs. (2) } \\
\text { and (3) }\end{array}$ \\
\hline $\begin{array}{l}\text { Eklund } \\
\text { et al. [110] }\end{array}$ & 1980 & $\begin{array}{l}\text { Patients with } \\
\text { obstructive } \\
\text { jaundice }\end{array}$ & EBD & $\begin{array}{l}\text { Cholic, chenodeoxycholic and hyocholic bile excretion } \\
\text { immediately increase following drainage }\end{array}$ \\
\hline $\begin{array}{l}\text { Chijiiwa } \\
\text { et al. [71] }\end{array}$ & 2002 & $\begin{array}{l}\text { Patients with } \\
\text { obstructive } \\
\text { jaundice }\end{array}$ & $\begin{array}{l}\text { EBD }>\text { PD }(n=4) \\
\text { EBD pylorus-preserving PD }(n=4) \\
\text { EBD }>\text { extended right HT }(n=1) \\
\text { EBD }>\text { extended left HT }(n=1)\end{array}$ & $\begin{array}{l}\text { Normal bile flow and bile salt secretion rates after EBD } \\
\text { Hepatic ATP: correlation with bile salt secretion, not with bile } \\
\text { flow }\end{array}$ \\
\hline
\end{tabular}

$\mathrm{IBD}=$ Internal biliary drainage; $\mathrm{EBD}=$ external biliary drainage

sequence, due to the compensatory mechanism for the continuous loss, peak concentrations of bile HGF are higher when external drainage is used, compared to internal drainage [69].

Following external biliary decompression, bile acid output decreases drastically and gradually increases again to reach a plateau in most patients [70]. In some cases, bile acid output remains low due to a delayed recovery of liver function [70]. The increase in bile acid output after the positioning of an external biliary drainage is dependent on the hepatic ATP content [71]. For these reasons, as for transplant surgery $[43,44]$, the hepatic energy status and hence organ viability influences the recovery of normal liver functions after relief of obstructive jaundice.

\section{Ex vivo Liver Perfusion}

Bile analysis has also been used as a measure of hepatic viability and function in ex vivo perfused porcine livers. These experimental models have been used to study liver physiology [72], metabolism [73] and the toxic effects of a wide range of inorganic and biological compounds [72, 73]. Foley et al. [74] used bile flow and phospholipid and cholesterol concentrations to examine differences between a single and a dual vessel porcine perfusion model. The dual vessel perfusion model (hepatic artery and portal vein) produced significantly more bile than single vessel perfusion (portal vein only) with more aqueous bile and a greater cholesterol output. However, the livers perfused from a single vessel did produce a greater output of phospholipid [74]. The same author used the composition of bile to investigate the potential of the ex vivo perfused liver to support 4 patients with fulminant hepatic failure [75]. Samples after $1 \mathrm{~h}$ of perfusion demonstrated the predominance of pig bile acids (65\%), but after $3 \mathrm{~h}$ human bile acids made up the largest fraction (85\%) [75]. 


\section{Discussion}

It is relatively straightforward to collect bile following liver surgery, and this has stimulated interest in its value as a tool to monitor and predict liver function in both clinical and research studies. Initial studies focused mainly on bile volume and composition, although other aspects were also examined including bile cytology, immunology and the influence of specific drugs on its production. All of these studies provided new insights in respect of the liver's response to various physiological and pathological conditions, and had important clinical applications in both liver transplantation and following resectional surgery.

Early studies where bile was analysed in detail greatly contributed to the understanding of the various aspects of OLTx per se as well as those which were influenced by immunosuppressive drugs/regimens, rejection and postoperative complications. At the end of the period of cold ischaemia and immediately following transplantion, the liver undergoes a period of 'stunning' or 'hibernation' that is related to the intracellular ATP content. The longer the ischaemia time, the more ATP is consumed within the cells and the longer the organ needs to recover its normal biosynthetic activities, including the synthesis and secretion of bile components. Additionally, the presence of an open T-tube (and consequent bile drainage) in the first few post-operative days also contributes to the observed alterations in bile physiology. Disruption of the enterohepatic circulation decreases the secretion of bile, which is directly dependent on the acid bile synthesis ('choleretic effect') and limits the synthesis of bile salts to those derived only from the primary acids. This increases the overall lithogenic index and the likelihood of calculi formation. Siphoning off the bile is responsible for those changes, and these are usually reversed by the closure of the external drainage and the restoration of the internal bile flow. The fact that both the cold ischaemia and the T-tube contribute to changes in the early postoperative days after OLTx makes it difficult to use bile production and analysis as a direct measure of the organ viability and functionality in this period. However, bile analysis could be especially useful immediately following the closure/removal of the T-tube as a diagnostic tool for primary organ non-functions or delayed organ recovery.

Other important findings in the field of liver transplantation correlate with the use of different immunosuppressive drugs and their influence on the bile production. Changes are often related to specific pharmacologic mechanisms of action of the drug (e.g. the cholestatic ef- fect of cyclosporine). Particular bile components (e.g. IL6 , HGF, $\beta_{2}$-microglobulin, number and types of cells) are also useful in predicting post-operative rejection as they are altered days before the appearance of symptoms. This makes them a useful and non-invasive tool for monitoring rejection in the early post-operative period. The same constituents are also reliable markers of the liver's response to anti-rejection therapy as they remained persistently elevated in cases that are resistant.

The importance of bile analysis in HPB surgery lies in its ability to predict post-operative liver failure. Monitoring of liver function includes the assessment of standard biochemical parameters, radiological estimates of residual functional volumes and assessments of the hepatocyte uptake and elimination (indocyanine green clearance) or metabolism (lignocaine or galactose) [76, 77]. A number of studies have shown that changes in the composition of bile provide a useful tool for the pre-operative screening and the early post-operative monitoring of patients at high risk of liver failure following HPB surgery. Pre-operative bile analysis might also be helpful in guiding the extent of resection or the need for an alternative pre-operative approach such as portal vein embolization. In the post-operative setting, it could provide an additional reliable method of monitoring the patient's clinical condition and possibly predict the need for additional treatment or a change of management. Bile analysis is likely to be most valuable as a complementary investigation augmenting those currently used, and would increase the overall sensitivity for the early and reliable detection of post-operative liver failure. Prospective studies should examine the predictive value and the sensitivity and specificity of each biliary parameter (bile volume, bile salt concentrations, bilirubin subfractions, biliary HGF of IL-6) at different time points after surgery and in sufficient detail to allow their integration into clinical practice. A direct comparison with the other methods already used in clinical practice, or with combinations of them, could possibly generate new scoring systems to increase the overall accuracy.

The findings in respect of biliary drainage (external and T-tubes) are similar for liver transplantation and major HPB surgery and both significantly affect the physiology of bile production. The differences observed between external and internal drainages demonstrate the importance of the enterohepatic circulation of bile salts and confirm that internal drainage results in less disturbance of normal physiologic conditions. The importance of the enterohepatic circulation is not limited to the bile salt content (which could potentially be replaced by the post- 
operative administration of taurocholic acid), but also involves specific molecules that are directly related to liver regeneration (e.g. HGF, IL-6) and that cannot be easily substituted. The loss of these substances with external drainages theoretically increases the risk of post-operative liver failure through a resultant decrease in hepatocyte regeneration after liver resection [76]. This requires confirmation, and prospective studies should evaluate the advantages of internal drains over the external to prevent liver failure in patients who require biliary drainage in the perioperative period.

\section{Conclusions}

Results of experimental and clinical studies confirm that changes in bile composition may be useful for monitoring the outcome of liver surgery. Future comparisons with the other methods are required and may demonstrate that its assessment is more reliable and could provide a valuable tool to be employed in a number of clinical situations, from the screening of organ rejection to the identification of patients at high risk of developing postoperative complications. Future studies should further examine the predictive value of alterations in bile composition to allow their definitive integration into clinical practice.

\section{References}

1 Vilca Melendez H, Rela M, Murphy G, Heaton $\mathrm{N}$ : Liver transplantation and bile analysis: a parallel evolution. Transplantation 1998;65:1289-1293.

$\checkmark 2$ Prandi D: Canalicular bile production in man. Eur J Clin Invest 1975;5:1-6.

-3 Ishiyama S, Fuse A, Kuzu H, et al: Altered biliary bilirubin profile in patients with persistent hyperbilirubinaemia after hepatic resection: analysis of bile bilirubin subfractions by high-performance liquid chromatography. J Gastroenterol Hepatol 1998;13:709-714.

4 Tanabe G, Sakamoto M, Akazawa K, et al: Intraoperative risk factors associated with hepatic resection. Br J Surg 1995;82:12621265.

5 Tjandra JJ, Fan ST, Wong J: Peri-operative mortality in hepatic resection. Aust N Z J Surg 1991;61:201-206.

6 Noguchi T, Imai T, Mizumoto R: Preoperative estimation of surgical risk of hepatectomy in cirrhotic patients. Hepatogastroenterology 1990;37:165-171.

7 Kurumiya Y, Nagino M, Nozawa K, et al: Biliary bile acid concentration is a simple and reliable indicator for liver function after hepatobiliary resection for biliary cancer. Surgery 2003;133:512-520.

8 Starzl TE, Marchioro TL, Vonkaulla KN, et al: Homotransplantation of the liver in humans. Surg Gynecol Obstet 1963;117:659676.

9 McMaster P, Walton RM, White DG, et al: The influence of ischaemia on the biliary tract. Br J Surg 1980;67:321-324.

10 Kuroki S, Okamoto S, Kosahara K, et al: Effect of biliary drainage on serum 7 alpha-hydroxycholesterol level in patients with obstructive jaundice. J Surg Res 1994;57: 352-359.
11 Okamoto S, Fukushima K, Higashijima H, et al: Serum 7 alpha-hydroxycholesterol reflects hepatic bile acid synthesis in patients with obstructive jaundice after external biliary drainage. Hepatology 1994;20:95-100.

12 Codoceo R, Jara P, Diaz MC, et al: Changes of bile acid profile and coagulation during orthotopic liver transplantation. Transplant Proc 1989;21:2351-2352.

13 Hemming AW, Scudamore CH, Shackleton $\mathrm{CR}$, et al: Indocyanine green clearance as a predictor of successful hepatic resection in cirrhotic patients. Am J Surg 1992;163:515518.

14 Herrera J, Codoceo R, Mora NP, et al: Bile acid profile as an early indicator of allograft function during orthotopic liver transplantation. Transplant Proc 1989;21:2313-2314.

15 Osada S, Saji S: The clinical significance of monitoring alkaline phosphatase level to estimate postoperative liver failure after hepatectomy. Hepatogastroenterology 2004;51: 1434-1438.

16 Suehiro T, Boros P, Sheiner P, et al: Effluent levels of thrombomodulin predict early graft function in clinical liver transplantation. Liver 1997;17:224-229.

17 Nagino M, Nimura Y, Hayakawa N, et al: Logistic regression and discriminant analyses of hepatic failure after liver resection for carcinoma of the biliary tract. World J Surg 1993;17:250-255.

18 Pitt HA, Gomes AS, Lois JF, et al: Does preoperative percutaneous biliary drainage reduce operative risk or increase hospital cost? Ann Surg 1985;201:545-553.

19 Hoshino M, Hirano A, Hayakawa T, et al: Comparative studies on bile flow and biliary lipid excretion after bile-acid loading in normal and partially hepatectomized rats. Biochem J 1995;305:367-371.
20 Liu ML, Mars WM, Zarnegar R, Michalopoulos GK: Uptake and distribution of hepatocyte growth factor in normal and regenerating adult rat liver. Am J Pathol 1994;144: 129-140.

21 Martineau G, Porter KA, Corman J, et al: Delayed biliary duct obstruction after orthotopic liver transplantation. Surgery 1972;72: 604-610.

22 Zieve L, Anderson WR, Lindblad S: Course of hepatic regeneration after 80 to $90 \%$ resection of normal rat liver. Comparison with two-lobe and one-lobe hepatectomy. J Lab Clin Med 1985;105:331-336.

23 Romagnoli J, Baiocchi L, Tisone G, et al: Qualitative patterns of biliary bile acids affect cyclosporine intestinal absorption in liver transplant recipients. Transplant Proc 1996;28:3129-3130.

24 Dietze O, Klima G, Königsrainer A, et al: Bile cytology versus pancreatic juice cytology for diagnosis of allograft rejection. Transplantation 1990;50:721-722.

25 Kubota K, Reinholt FP: Our experience with bile cytology and pancreatic juice cytology. Transplantation 1990;50:722-723.

26 McMaster P: Bile studies after liver transplantation. Ann R Coll Surg Engl 1979;61: 435-440.

$27 \mathrm{Xu}$ HS, Pilcher JA, Jones RS: Physiologic study of bile salt and lipid secretion in rats after liver transplantation. Ann Surg 1993; 217:404-412.

28 Chan FK, Zhang Y, Sutherland FR, Shaffer EA: Effects of liver transplantation on bile formation and biliary lipid secretion in the Sprague-Dawley rat. Hepatology 1995;22: 1254-1258.

29 Chan FK, Zhang Y, Lee SS, Shaffer EA: The effects of liver transplantation and cyclosporine on bile formation and lipid composition: an experimental study in the rat. J Hepatol 1998;28:329-336 
-30 Le Thai B, Dumont M, Michel A, et al: Cholestatic effect of cyclosporine in the rat. An inhibition of bile acid secretion. Transplantation 1988;46:510-512.

-31 Chan FK, Shaffer EA: Cholestatic effects of cyclosporine in the rat. Transplantation 1997;63:1574-1578.

-32 McCashland TM, Donovan JP, Amelsberg A, et al: Bile acid metabolism and biliary secretion in patients receiving orthotopic liver transplants: differing effects of cyclosporine and FK 506. Hepatology 1994;19:1381-1389.

>33 Ko CW, Kowdley KV, Haigh WG, Lee SP: Biliary lipid composition after liver transplantation: effect of allograft function and cyclosporine. Liver Transpl Surg 1998;4:258-264.

-34 Ericzon BG, Eusufzai S, Söderdahl G, et al: Secretion and composition of bile after human liver transplantation: studies on the effects of cyclosporine and tacrolimus. Transplantation 1997;63:74-80.

\35 Vilca Melendez H, Rela M, Setchell KD, et al: Bile acids analysis: a tool to assess graft function in human liver transplantation. Transpl Int 2004; 17:286-292.

>36 Geuken E, Visser D, Kuipers F, et al: Rapid increase of bile salt secretion is associated with bile duct injury after human liver transplantation. J Hepatol 2004;41:1017-1025.

\$37 Buis CI, Geuken E, Visser DS, et al: Altered bile composition after liver transplantation is associated with the development of nonanastomotic biliary strictures. J Hepatol 2009;50:69-79.

$\checkmark 38$ Ericzon BG, Eusufzai S, Kubota K, et al: Characteristics of biliary lipid metabolism after liver transplantation. Hepatology 1990; 12:1222-1228.

>39 Baiocchi L, Tisone G, Nistri A, et al: Sequential changes in serum and biliary bile acids after liver transplantation. Transplant Proc 1995;27:3503-3504.

40 Tisone G, Angelico M, Baiocchi L, et al: Patterns of bile salts and biliary lipids early after liver transplantation differentiate patients with unfavorable graft outcome. Transplant Proc 1996;28:1655-1656.

-41 Baumgartner U, Schölmerich J, Kremer B, et al: Early detection of graft dysfunction after orthotopic liver transplantation in man by serum and biliary bile acid analysis. Hepatogastroenterology 1995;42:950-960.

-42 Sánchez-Bueno F, Carrasco L, Ayala M, et al: Is lipid analysis of bile useful in the diagnosis of graft complications in liver transplantation? Transplant Proc 2000;32:2654-2656.

43 Kamiike W, Nakahara M, Nakao K, et al: Correlation between cellular ATP level and bile excretion in the rat liver. Transplantation 1985;39:50-55.

44 Kamiike W, Burdelski M, Steinhoff G, et al: Adenine nucleotide metabolism and its relation to organ viability in human liver transplantation. Transplantation 1988;45:138143.
45 Adams DH, Burnett D, Stockley RA, Elias E: Patterns of leukocyte chemotaxis to bile after liver transplantation. Gastroenterology 1989;97:433-438.

46 Hathaway M, Burnett D, Elias E, Adams DH: Secretion of soluble chemotactic factors, including interleukin-6: a mechanism for the recruitment of CD8-positive T lymphocytes to human liver allografts during rejection. Hepatology 1993;18:511-518.

47 Cressman DE, Greenbaum LE, DeAngelis RA, et al: Liver failure and defective hepatocyte regeneration in interleukin-6-deficient mice. Science 1996;274:1379-1383.

48 Umeshita K, Monden M, Tono T, et al: Determination of the presence of interleukin- 6 in bile after orthotopic liver transplantation. Its role in the diagnosis of acute rejection. Ann Surg 1996;223:204-211.

49 Adams DH, Burnett D, Stockley RA, et al: Biliary beta 2-microglobulin in liver allograft rejection. Hepatology 1988;8:15651570 .

50 Adams DH, Wang L, Hubscher SG, et al: Soluble interleukin-2 receptors in serum and bile of liver transplant recipients. Lancet 1989;1:469-471

51 Carrasco L, Sanchez-Bueno F, Sola J, et al: Use of bile cytology for early diagnosis of complications in orthotopic liver transplantation. Cytopathology 1998;9:406-414.

52 Kubota K, Ericzon BG, Barkholt L, Reinholt FP: Bile cytology in orthotopic liver transplantation. Transplantation 1989;48:9981003.

53 Roberti I, Lieberman KV, Manzarbeitia C, et al: Evidence that the systematic analysis of bile cytology permits monitoring of hepatic allograft rejection. Transplantation 1992;54: 471-474.

54 Fukano S, Saitoh Y, Uchida K, et al: Bile acid metabolism in partially hepatectomized rats. Steroids 1985;45:209-227.

55 Perez-Barriocanal F, Gonzalez J, Esteller A: Biliary lipid secretion in the regenerating liver of the rat. Br J Exp Pathol 1987;68:1-6.

56 Xu HS, Rosenlof LK, Jones RS: Bile secretion and liver regeneration in partially hepatectomized rats. Ann Surg 1993;218:176-182.

57 Hotta T, Kobayashi Y, Taniguchi K, et al: Liver functional analysis by total bile acid level of C-tube bile after hepatectomy. Hepatogastroenterology 2005;52:1211-1215.

58 Yamashita M, Adachi Y, Yamamoto T: Analysis of bilirubin conjugates in human bile by liquid chromatography. Changes in their composition in hepatobiliary diseases. J Gastroenterol Hepatol 1987;2:181-190.

59 Igarashi Y, Ishiyama S, Urayama M, et al: Experimental study on the bilirubin metabolism after major hepatectomy: alterations in the proportions of bile bilirubin subfractions. J Surg Res 1999;82:67-72.

60 Suto K, Fuse A, Igarashi Y, Kimura W: Significance of altered bilirubin subfractions in bile following hepatectomy. J Surg Res 2002; 106:62-69.
61 Takeuchi E, Nimura Y, Nagino M, et al: Human hepatocyte growth factor in bile: an indicator of posthepatectomy liver function in patients with biliary tract carcinoma. Hepatology 1997;26:1092-1099.

62 Kurumiya Y, Nimura Y, Takeuchi E, et al: Active form of human hepatocyte growth factor is excreted into bile after hepatobiliary resection. J Hepatol 1999;30:22-28.

63 Maeda A, Nagino M, Takeuchi E, et al: Interleukin 6 in bile as an indicator of liver function after hepatectomy in patients with biliary tract carcinoma. Br J Surg 1999;86: 458-464.

64 Suzuki H, Iyomasa S, Nimura Y, Yoshida S: Internal biliary drainage, unlike external drainage, does not suppress the regeneration of cholestatic rat liver after partial hepatectomy. Hepatology 1994;20:1318-1322.

65 Saiki S, Chijiiwa K, Komura M, et al: Preoperative internal biliary drainage is superior to external biliary drainage in liver regeneration and function after hepatectomy in obstructive jaundiced rats. Ann Surg 1999;230: 655-662.

66 Mizuta A, Chijiiwa K, Saiki S, et al: Differences in biliary lipid excretion after major hepatectomy in obstructive jaundiced rats with preoperative internal, external, or no biliary drainage. Eur Surg Res 2002;34:291299.

67 Iyomasa S, Terasaki M, Kuriki H, et al: Decrease in regeneration capacity of rat liver after external biliary drainage. Eur Surg Res 1992;24:265-272.

68 Nakamura T, Nawa K, Ichihara A: Partial purification and characterization of hepatocyte growth factor from serum of hepatectomized rats. Biochem Biophys Res Commun 1984;122:1450-1459.

69 Hayata A, Takeuchi E, Nagino M, et al: Hepatocyte growth factor concentration in rat bile is affected by hepatic resection volume and external biliary drainage. J Surg Res 1999;85:71-76

70 Yanagisawa J, Ichimiya H, Kuwano N, Nakayama F: The role of preoperative biliary decompression in the treatment of bile duct cancer. World J Surg 1988;12:33-38.

71 Chijiiwa K, Mizuta A, Ueda J, et al: Relation of biliary bile acid output to hepatic adenosine triphosphate level and biliary indocyanine green excretion in humans. World J Surg 2002;26:457-461.

72 Abouna GM, Ashcroft T, Hull C, et al: The assessment of function of the isolated perfused porcine liver. Br J Surg 1969;56:289295.

73 Powell GM, Hughes HM, Curtis CG: Isolated perfused liver technology for studying metabolic and toxicological problems. Drug Metabol Drug Interact 1989;7:53-86.

74 Foley DP, Vittimberga FJ, Quarfordt SH, et al: Biliary secretion of extracorporeal porcine livers with single and dual vessel perfusion. Transplantation 1999;68:362-368. 
75 Foley DP, Collins BR, Magee JC, et al: Bile acids in xenogeneic ex-vivo liver perfusion: function of xenoperfused livers and compatibility with human bile salts and porcine livers. Transplantation 2000;69:242-248.

76 Garcea G, Maddern GJ: Liver failure after major hepatic resection. J Hepatobiliary Pancreat Surg 2009;16:145-155.

77 Garcea G, Ong SL, Maddern GJ: Predicting liver failure following major hepatectomy. Dig Liver Dis 2009;41:798-806.

-78 Tono T, Monden M, Yoshizaki K, et al: Biliary interleukin 6 levels as indicators of hepatic allograft rejection in rats. Transplantation 1992;53:1195-1201.

79 Daloze P, Fourtanier G, Beaudouin M, et al: Biliary function after liver transplantation. Transplant Proc 1977;9:309-312.

-80 Chan FK, Zhang Y, Shaffer EA: Bile secretory function of the arterialized versus nonarterialized rat liver allograft. Transplantation 1996;62:1657-1663.

-81 Bell P, Homatas J, MacSween R, Brettschneider L: Bile secretion following orthotopic transplantation of the liver in dogs. Surg Forum 1969;20:295-297.

82 Le Thai B, Dumont M, Michel A, et al: Cyclosporine-induced cholestasis: inhibition of bile acid secretion is caused by the parental molecule. Transplant Proc 1987;19:41494151.

-83 Stone BG, Udani M, Sanghvi A, et al: Cyclosporin A-induced cholestasis. The mechanism in a rat model. Gastroenterology 1987; 93:344-351

84 Stone B, Warty V, Dindzans V, Van Thiel D: The mechanism of cyclosporine-induced cholestasis in the rat. Transplant Proc 1988; 20(suppl 3):841-844.

-85 Bowers BA, Branum GD, Rotolo FS, et al: Bile flow - an index of ischemic injury. J Surg Res 1987;42:565-569.

86 Javitt NB, Fortner JG, Shiu MH: Bile salt syn thesis in transplanted human liver. Gastroenterology 1971;60:405-408.

87 Baiocchi L, Tisone G, Falasca L, et al: Assembly of biliary lipids in native hepatic bile after orthotopic liver transplantation: a biochemical and ultra-structural study in humans. Hepatol Res 2006;35:215-221.
88 Goresky CA, Gordon ER, Sanabria JR, et al: Changes in bilirubin pigments secreted in bile after liver transplantation. Hepatology 1992;15:849-857.

89 Haagsma EB, Huizenga JR, Vonk RJ, et al: Composition of bile after orthotopic liver transplantation. Scand J Gastroenterol 1987; 22:1049-1055

$\checkmark 90$ Shiffman ML, Carithers RL Jr, Posner MP, Moore EW: Recovery of bile secretion following orthotopic liver transplantation. J Hepatol 1991;12:351-361.

91 Waldram R, Williams R, Calne RY: Bile composition and bile cast formation after transplantation of the liver in man. Transplantation 1975; 19:382-387.

$\$ 92$ Lenzen R, Bahr A, Eichstadt H, et al: In liver transplantation, $\mathrm{T}$ tube bile represents total bile flow: physiological and scintigraphic studies on biliary secretion of organic anions. Liver Transpl Surg 1999;5:8-15.

$\$ 93$ Bowers BA, Rotolo FS, Watters CR, et al: Regulation of biliary secretion following liver transplantation. Transplant Proc 1989;21: 3554

94 Umeshita K, Monden M, Tono T, et al: Interleukin- 6 in bile as a marker of allograft rejection following liver transplantation in man. Transplant Proc 1992;24:1462-1464.

95 Ericzon BG, Eusufzai S, Kubota K, et al: Biliary lipid secretion early after liver transplantation. Transplant Proc 1990;22:1537-1538.

96 Theilmann L, Otto G, Arnold J, et al: Biliary secretion of bile acids, lipids, and bilirubin by the transplanted liver. A quantitative study in patients on cyclosporine. Transplantation 1991;52:1020-1023.

97 Carrasco L, Sánchez-Bueno F, Sola J, et al: Is exfoliative bile cytology useful in the diag nosis of graft complications in liver transplantation? Transplant Proc 1995;27:22812282.

$>98$ Oldhafer KJ, Gubernatis G, Ringe B, Pichlmayr R: Experience with bile cytology after liver transplantation. Transplant Proc 1990; 22:1524.

99 Kubota K, Ericzon BG, Reinholt FP: The correlation between cytological patterns in bile and histological findings in liver transplantation. Transplantation 1992;53:791-795.
100 Kubota K, Ericzon BG, Reinholt FP: Diagnosis of liver transplant rejection by bile cytology. Transplant Proc 1990;22:1521-1523.

101 McMaster P, Herbertson B, Cusick C, et al: Biliary sludging following liver transplantation in man. Transplantation 1978;25:5662.

102 McMaster P, Herbertson BM, Cusick C, et al: The development of biliary 'sludge' following liver transplantation. Transplant Proc 1979;11:262-266.

103 Söderdahl G, Groth CG, Angelin B, et al: FK 506 improves recovery of bile secretion following orthotopic liver transplantation in man. Transplant Proc 1995;27:1125.

104 Sauer P, Rudolph G, Endele R, et al: Kinetics of primary bile acids in patients after orthotopic liver transplantation. Eur J Clin Invest 1996;26:979-982.

105 Hathaway M, Adams DH, Burnett D, Elias E: Secretion into bile of chemotactic factors for CD8+ lymphocytes during rejection of human liver allografts. Transplant Proc 1991;23:1424-1425.

106 Akamatsu Y, Ohkohchi N, Seya K, Satomi S: Analysis of bilirubin fraction in the bile for early diagnosis of acute rejection in living related liver transplantation. Tohoku J Exp Med 1997;181:145-154.

107 Adams DH, Hubscher SG, Burnett D, Elias E: Immunoglobulins in liver allograft rejection: evidence for deposition and secretion within the liver. Transplant Proc 1990; 22:1834-1835.

108 Hathaway M, Adams DH, Burnett D, Elias E: Recruitment of lymphocytes to human liver allografts during rejection. Transplant Proc 1990;22:2306-2307.

109 Carrasco L, Sanchez-Bueno F, Sola J, et al: Effects of cold ischemia time on the graft after orthotopic liver transplantation. A bile cytological study. Transplantation 1996;61:393-396.

110 Eklund A, Norlander A, Norman A: Bile acid synthesis and excretion following release of total extrahepatic cholestasis by percutaneous transhepatic drainage. Eur J Clin Invest 1980;10:349-355. 